\title{
Accessible television: The new frontier in disability media studies brings together industry innovation, government legislation and online activism by Katie Ellis and Mike Kent
}

\begin{abstract}
As television moves beyond digital broadcast modes of distribution towards online modes of delivery, this paper considers the opportunities and challenges for people with disabilities. With accessibility relying on a complex mix of regulation, legislation and industry innovation, the paper questions whether predictions of improved accessibility are an automatic outcome of new television technologies. The paper asks 'where to next?' for disability and the Internet through an emphasis on the importance of television in an accessible new media environment. The paper draws on government policies, the activist intervention of a number of people with disabilities as documented online, and primary research into Australian television audiences with disabilities that took place in 2013 and 2014.
\end{abstract}

\section{Contents}

Introduction

Television in disability media and Internet studies

United Nation's Convention on the Rights of Persons with Disabilities (UNCRPD)

Digital and online television

Online vs. broadcast television accessibility

$\underline{\text { Conclusion }}$

\begin{abstract}
Introduction
On 14 April 2015 subscription video on demand (VOD) provider Netflix announced it would provide audio description of its original content (Daredevil, House of Cards, Orange is the New Black) for its vision impaired audience (Netflix, 2015). Previously Netflix had responded that it had 'no immediate plans' to make their content accessible to viewers with vision impairment when questioned by the Accessible Netflix Project (ANP) (Kingett, 2014a; Ellis, 2015). It is unclear whether Netflix back flipped in response to consumer demand and agitation such as petitions and negative publicity or if the plan was to introduce audio description all along. The controversy certainly generated a lot of attention for its new blind superhero themed offering Daredevil which, ironically, was initially released without audio description and then became the first to feature it.
\end{abstract}

While a television show featuring a character with an impairment such as Daredevil's Matt Murdock's vision impairment would be of interest to theorists in critical disability studies, the question of whether the program itself is accessible to viewers with the same impairment has not garnered much attention. This paper considers the changing nature of television as it transitions to the Internet and the implications this has for people with disabilities. The paper calls for an incorporation of accessibility to a broader discussion of disability and television, particularly as content becomes digital (Ellcessor, 2012; Ellis, 2014; Ellis and Goggin, 2015; Ellis and Kent, 2011; Goggin and Newell, 2003; Utray, et al., 2012). Digital media theorisation - and Internet studies in particular - has much to offer critical disability studies.

Accordingly, the paper begins with a discussion of the important yet peripheral position of television to discussions of accessible digital media before moving on to the United Nation's Convention on the Rights of Persons with Disabilities (UNCRPD) as it pertains to the provision of accessible television. The paper then considers the potential new television technologies such as digital and online television represent for the accessible provision of this media. The paper then turns specifically to the Australian context to consider legislation in that country regarding the provision of captions, audio description and sign language accessibility features on broadcast and online television. Comparisons are made to the regulatory environments in both the United States and United Kingdom. The paper concludes with an examination of the ongoing activist intervention occurring online of people with disabilities seeking a more accessible television viewing experience as television transitions to online platforms. The paper 
concludes with reflections on the increasing importance of internet and media studies to disability studies.

\section{Television in disability media and Internet studies}

As discussed by other papers in this special issue, disability Internet studies has much to offer disability theorisation by highlighting issues related to accessibility and useability. As television transitions to the Internet this will be a key site in which these issues play out, particularly because customisable content is a key feature of the evolving televisual environment. Television has been addressed somewhat peripherally in the three key texts in this field of study - Digital disability (Goggin and Newell, 2003), Disability and new media (Ellis and Kent, 2011) and Disability and the Internet (Jaeger, 2012).

In 2003 Gerard Goggin and Christopher Newell argued that despite being a culturally ubiquitous social connector, 'for many people with disabilities [television] has been a difficult to see or hear, impossible to watch or listen to, absent cultural technology' [1]. In keeping with their broader argument in digital disability that new technologies disable as well as enable, they identify television, alongside mobile telephones and the Internet, as forms of new media which, although presented as a panacea in modern societies, continue to create disability. They described the at the time impending digitisation of television as offering the potential to remove access barriers experienced by people with disabilities yet cautioned that disability could continue to be built into the technology if accessible features such as captions and audio description were not embraced.

In our 2011 book we were concerned with television's move towards digital modes of delivery such as the Internet and identified a number of examples where the transition further disabled people with impairments, such as Netflix's refusal to incorporate captions on their streaming platforms, Apple's inaccessible interfaces, a lack of captions on catch up television despite their provision on DVD release, the unwillingness of governments to legislate in this area, and the introduction of new television technologies without accessibility in place. We also found that major networks were less willing to embrace accessibility than independent producers and ordinary Internet users generating their own content on sites such as YouTube.

Paul Jaeger's (2012) concern with television, like Goggin and Newell (2003), extends across both representation and accessibility. While acknowledging that representations have increased in recent history, Jaeger expresses continuing disappointment in a lack of accuracy around the disability experience [2]. He posits that the Internet should be the 'ideal tool' to 'treat people with disabilities as human beings' [ $\underline{3}$ ] by allowing more accurate forms of representation and opportunity for participation.

Acknowledging the importance of accessibility, Jaeger notes the significant role of legislation in ensuring accessible television and new media yet cautions, as do a number of contributors to this special issue, that guidelines are rarely enforced. The Twenty-First Century Communications and Video Accessibility Act of 2010 is of particular interest for Jaeger who observes that 'more than half' of the requirements relate to television [4].

Drawing on the intervention of people with disabilities that Jaeger (2012) alludes to in his discussion of the opportunities the Internet represents for people with disabilities to 'influence the social norms, social types, information value, and information behaviour of society at large and across the lifeworld of information in society' [ $\underline{5}$ ], this paper seeks to emphasise the importance of television in an accessible new media environment. With accessibility relying on a complex mix of regulation, legislation and industry innovation, the paper questions whether predictions of improved accessibility are an automatic outcome of new television technologies.

\section{United Nation's Convention on the Rights of Persons with Disabilities (UNCRPD)}

Goggin and Newell (2003), Ellis and Kent (2011) and Jaeger (2012) all identify television as an important site of social inclusion and argue that the exclusion of people with disabilities is an issue that must be addressed. The social inclusion of people with disability is an issue explicitly addressed by the UNCRPD. The right to access television appears several times in the UNCRPD. It is specifically mentioned in Article 30, point 1b (United Nations, 2006):

States Parties recognize the right of persons with disabilities to take part on an equal basis with others in cultural life, and shall take all appropriate measures to ensure that persons with disabilities:

(a) Enjoy access to cultural materials in accessible formats;

(b) Enjoy access to television programmes, films, theatre and other cultural activities, in accessible formats (22).

In addition, the preamble to the UNCRPD recognises the importance of accessibility in 'enabling persons with disabilities to fully enjoy all human rights and fundamental freedoms', with particular reference to the physical, social, economic and cultural environment, health and education and information and communication. Communication is defined as: 
languages, display of text, Braille, tactile communication, large print, accessible multimedia as well as written, audio, plain-language, humanreader and augmentative and alternative modes, means and formats of communication, including accessible information and communication technology (4).

The significance of television can also be interpreted in articles 4, 5, 9, 21, 30 and 32.

Significantly, this convention puts access to communications on an equal level to the built environment. The convention also makes provisions for new or emerging technologies. As a signatory to the 2006 UNCRPD, the Australian government recognises that people with disabilities have a right to access communications technology and cultural information (United Nations, 2006). Digital and online television could potentially offer greater access to this information for people with disabilities, particularly those with vision, hearing and physical impairments (Ellis, 2012; Robare, 2011; Slater, et al., 2010); however, this is far from automatic.

\section{Digital and online television}

Television has undergone a number of technological changes, including the introduction of colour, the adoption of the remote control, stereo sound, VCRs, DVDs and, most recently, digital television and online modes of delivery such as Internet TV, downloading TV on tablets and broadband based television. TV itself can be seen as a technological shift from radio. Originally much of the early television content was adapted from pre-existing radio programming. Each shift can be implicated in broader discussions about accessibility for people with disabilities. The radio serial necessarily contained audio description of what was happening (although was not accessible for people with hearing impairments). For television, Cronin and King (1998) argued that with the adoption of stereo sound, audio description would become more widely available for viewers with vision impairments. Conversely, Law and Vanderheiden (1998) found that as VCRs became more accessible to the non-disabled population in the late 1990 s, they became less accessible to people with disabilities. More recently, Media Access Australia note that only 25 percent of DVDs released in Australia include audio description, while 55 percent include captions (Media Access Australia, 2012b).

The introduction of digital television throughout the world initiated changes in the amount of information that could be delivered via this media and increased flexibility for 'broadcasters ... to manipulate the form in which that information is presented to the viewer' [ 6 ].

Digital television - which contains up to six times more data than analogue signals (Weber and Evans, 2002) - offers greater flexibility and increased opportunity for alternative formats for people with disabilities as Springett, Rice and Griffiths explain:

Accessibility services to audio-visual content through sign language, subtitles and audio description have become vital forms of interaction for deaf and hard of hearing, those with low literacy or learning disabilities, and blind and partially sighted people. [?]

They argue that, despite this, there remain a significant number of people who struggle to adapt to the emerging technology, including people with disability. Similarly, as several theorists explain, new technologies lauded as empowering for people with disability are not necessarily immediately accessible (Annable, et al., 2007; Ellis and Kent, 2011; Pedlow, 2008; Wentz, et al., 2013). For Wentz, et al., this is a result of ableist decision-making:

There is nothing about technology that makes it inherently accessible or inaccessible. Most of today's technologies are digital, meaning that they are made up of zeros and ones, and there is nothing inherently visual or auditory about zeros and ones. Digital information is not inherently accessible or inaccessible, but the choices made by those developing and implementing technology determine whether a technology ultimately will be accessible or inaccessible.

For Utray, et al., providing accessible digital television is a human rights issue as mandated by the 2006 UNCRPD. They offer a breakdown of the minimum accessibility options that should be available on television in order to compensate for the effects of a number of impairments:

Vision: audio description of programming as well as interactive services such as the electronic program guide (EPG), and enhanced graphical user interfaces.

Hearing: subtitles available for 100 percent of the broadcast content, sign language avatars for newscasts, documentaries, and education programmes and a clean audio service available for dramatic or fictional contents.

Dexterity: interactive navigation systems and ergonomics of hardware and software to be adapted to individual needs which vary significantly from person to person, impairment to impairment. 
[The] elderly and people with intellectual disabilities: can benefit from any of the above provided they follow a "design for all" strategy. (Utray, et al., 2012)

These options are essential to the full inclusion of people with disability and could result in an improved television experience for everyone (Ellis, 2012; Sinclair, et al., 2007; Utray, et al., 2012). With television now moving to Internet platforms - including IPTV, Internet television, online television and streaming media - the issue of accessibility is being revisited by broadcasters, legislators and users.

To draw on the Australian example, whereas the government in its Review into access To electronic media for the hearing and vision-impaired (Australia. Department of Broadband, Communications and the Digital Economy, 2010) argued that accessibility features would become widespread online and on digital television as a result of industry innovation, a recent report by the European Union found that accessibility is more widely available on digital and online television in countries where legislation is in place (Kubitschke, et al., 2013).

\section{Online vs. broadcast television accessibility}

A disproportionate system currently exists in Australia and elsewhere regarding the provision of accessibility features on broadcast and online television. This section reports the current state of play regarding captions, audio description and sign language on Australian broadcast and online television, making comparisons to the U.S. and the U.K.

\section{Captions}

To begin with captions, whereas 100 percent of content broadcast on free to air television between 6 AM and midnight must be captioned according a 2014 update to the Broadcasting Services Act (1992) there is no legislation in place regarding online television. Indeed programmes rescreened online as a form of 'catch up' television do not include captions despite their availability in other formats such as broadcast and DVD release.

As previously mentioned, the video streaming Web site Netflix was heavily criticised for adopting this same strategy in 2009 (Ellcessor, 2012; Ellis and Kent, 2011). Netflix has since been forced to commit to captioning 100 percent of its content under an Americans with Disabilities Act (ADA) complaint (Mullin, 2012; Wolford, 2012). Significantly, as a result of this ruling, legal commentators began recommending businesses make their Web sites compatible as a matter of course (Goren, 2012). However, a federal appeals court later found Netflix does not have to comply with the ADA because it is not connected to any 'actual physical place' (Hattem, 2015). These contradictory interpretations of the $A D A$ have reignited the confusion around whether the Internet constitutes a place of public accommodation.

After the first ruling, commentators in the U.K. considered the possible legal implications in that country where the video streaming service LoveFilm (now called Amazon Prime) did not yet offer captions (Hassell, 2012). LoveFilm, which argued that hearing impaired viewers could access an equivalent service through their DVD releases, was the target of activist intervention of people with disabilities during the \#subtitlesnow day of action organised by Pesky People (2012). LoveFilm continues to be criticised by people with disabilities for not offering captions on their streaming videos (Kukiewicz, 2013; Palmer, 2014). However, Quickflix, another Australian streaming service, offers captions on their streaming content if they are provided by the distributing studio (Ellis, 2015).

In the U.K., whereas at least 90 percent of content on Channels 3 and 4 , and 80 percent content on all other channels must be subtitled on broadcast television, there are no legislative requirements regarding the provision of captions on online television (United Kingdom, 2003). While the Authority for Television on Demand (ATVOD) encourages the provision of captions, it does not possess the regulatory authority to impose captioning quotas on the VOD industry. Panel discussions at the Future of Subtitling Conference held in London in late 2014, however, concluded that the U.K. VOD industry 'has two years to prove that it can deliver reasonable access for deaf people or it will face the government introducing mandatory regulation' (Media Access Australia, 2014). The Australian pay television VOD offering Foxtel Movies on Demand, which captions 80 percent of movies, was cited at the conference as an example of 'reasonable progress' (Media Access Australia, 2014).

By comparison, in the U.S., as a result of the Twenty-First Century Television and Video Accessibility Act, all pre-recorded content which has been shown with captions on broadcast television must be captioned online. Similarly, live content captioned for broadcast must also be offered with captions online. Content which is shown on the Internet and then on television must currently be captioned within 45 days of the date it appears on television. By 2016, this falls to 15 days (U.S. Federal Communications Commission (FCC), 2014).

The Twenty-First Century Communication and Video Accessibility Act also requires all video distributors - including cable operators, broadcasters, satellite distributors and other multi-channel video programming distributors - to caption 100 percent of their new programming and up to 75 percent of their pre-rule programming. Exemptions apply to programmes broadcast in languages other than English and Spanish, textual based programmes, those shown between 2 AM and 6 AM and when the costs of captioning exceeds two percent of gross revenues, and channels with revenues under US $\$ 3,000,000$ per year (Cornell University Law School, 2010). 
Finally, standards exist to regulate accuracy, synchronicity, completeness and placement. However, as Ellcessor argues, this does not always result in an equitable viewing experience for people with hearing impairments, particularly when captions are automated (Ellcessor, 2014).

\section{Audio description}

Despite Australia's recognition of the importance of captions as reflected in the Broadcasting Services Act, there is no legislation in place regarding the provision of audio descriptions on Australian television. While a coalition of people with vision impairment have taken the government and the public broadcaster the $A B C$ to court over this issue (Ellis, 2014), a trial of the provision of audio description on the online $A B C$ catch up television media player iView has recently been announced (Vision Australia, 2014).

By comparison, legislation regarding audio description is in place in a number of other countries including the U.K., U.S. and Canada.

To begin in the U.S., in 2000, the U.S. Federal Communications Commission (FCC) directed 'the four big TV networks and the five biggest cable networks to show 50 hours of audio described programmes per quarter by April 2002' [8]. While the mandate was overturned when the U.S. Supreme Court ruled in favour of a challenge to the rule launched by the Motion Picture Association in 2002, the networks had already begun to comply. When the Twenty-First Century Communications and Video Accessibility Act came into effect in 2010, the FCC's rules mandating four hours of audio described content per week were restored (Media Access Australia, 2012a). However, like Australia, there is no legislation in place regarding the provision of audio described content on online television.

By comparison, audio description targets have been a condition of television licence renewal in Canada for the past 14 years (Mikul, 2010). Significantly, Canada has the world's only fully audio accessible channel (called the Accessible Channel) on which the audio description is open, meaning everyone can hear it [9]].

In the U.K., audio description is regulated by OfCom's Code on Television Access. Section 8 of this code stipulates audio description targets of 10 percent of content after five years of broadcasting while still allowing for some exemptions if audience share is less than 0.05 percent, or where there are technical or financial difficulties (OfCom, 2012). However, following the introduction of this code, broadcasters began exceeding their minimum requirements, with some achieving 100 percent (OfCom, 2013).

According to OfCom's subtitling, signing and audio description page (OfCom, 2014b), BBC iPlayer and S4C's Clic are required to comply with the regulations regarding audio description. However, other ondemand services are not currently required under the legislation to provide access services. ATVOD who are 'required to encourage service providers to make their services progressively more accessible to people with sensory impairment' (OfCom, 2014b), invite users to inform them when accessibility issues arise.

The ATVOD's Access Services Plan for 2014 to 2016 notes that the Communications Act of 2003 does not provide regulations which require online service providers to meet subtitling, audio description or signing quotas [10]. According to ATVOD's Provision of Video on Demand Access Services 2013 Report, Sky and Channel 4 both provide some content which has audio description [11]. In 2013, Sky provided audio description for 21 percent of their content, while Channel 4 provided 13 percent [12]. The report claims that there are a further five providers who intend to provide audio description in the future BT, Channel 5, ITV, Chelsea TV and Discovery [13].

Yet in the Australian context, legislation regarding the provision of audio description remains a nonpriority (Blind Citizens Australia, 2013). Indeed, some Australian produced programmes are audio described in the U.K. but not in Australia.

\section{Sign language}

While sign language has historically only been visible on television during emergency broadcasts or dedicated programming, Slater, et al. (2010) argue that, in the context of digital and broadband television, signing is an area which shows 'great promise' through the opportunity to personalise the viewing experience. They note signing avatars represent a significant shift in the potential availability of 'closed signing' or signing which is only available when the option is selected, in much the same way as closed captions. However, these images take up a considerable amount of data which broadcasters would prefer to use on more channels rather than better services for the disabled (Slater, et al., 2010). They also note that hybrid broadcast/broadband services are being developed where:

The program being signed is delivered over a broadcast network terrestrial, cable or satellite - and the video of the signer is provided on-demand over a wired broadband IP connection. The hybrid broadcast/broadband delivery solution enables broadcasters to make the best use of their bandwidth to target the majority of their viewers, whilst the broadband system is ideal for providing extra information (the detailed moving video of the signer) directly to the receivers of those who require it.

These developments are an example of the importance of industry innovation. However, at this time, no legislation exists in Australia nor the U.S. regarding the provision of sign language on television, broadcast or online. In the U.K., however, at least five percent of every service must be presented in, or translated to, sign language (OfCom, 2014a). According to OfCom's Television Access Services Report for the first six months of 2013, 14 of the services met or exceeded the five percent target while 
two did not (BBC HD2 and S4C). The report also shows that of the remaining services, a large majority have made alternative arrangements, as permitted by the code (OfCom, 2013).

Online activism

A number of activists with disabilities have turned to online platforms to argue for an improved delivery of accessible television, either online or via broadcast. Whereas in 2009, Deaf activists sent letters in protest of the lack of captions on Netflix's free screening of the Wizard of Oz (Ellcessor, 2012), in 2013, Robert Kingett, a Netflix viewer who requires audio descriptions, began a popular online community the ANP - to encourage the streaming service to make their content more accessible (Kingett, 2014a).

ANP community members traverse a number of online platforms, including blogs, YouTube videos and social media engagement, to advocate that Netflix embrace accessibility for people with vision impairments. Their stated mission is to (Kingett, 2014a):

1. Provide accessible software and interface to Netflix users.

2. Implement and ensure future accessibility practices and consideration.

3. Ensure that relatively all types of disability are taken into careful consideration at all times.

Netflix has frequently been a source of protest, with bloggers highlighting inadequacies with the service such as captions which do not reflect either the tone or intention of the dialogue being captioned:

Most of the time the closed captioning is pretty spot on. Networks are pretty good about it and video games, too, transcribe word for word inhouse because they know the dialogue. And while [Netflix] offers subtitles on an increasing amount of content - and you plan to offer it on all of that programming by 2014 - that doesn't mean that the subtitles are offering the same experience. (Wildman, 2013)

Another blogger questioned what value they receive as a Netflix consumer in an open letter to Reed Hastings, co-founder and CEO of Netflix: 'I am now faced with answering the question of what value I get from your streaming service' (Joehl, 2011). Although applauding developments in accessibility, this consumer wants more, noting the importance of accessibility across hardware and content:

Accessibility at your company would involve three components: (1) the Web site for accessing Netflix services, (2) the media player used for streaming content, and (3) the content itself to be provided via multiple modalities to accommodate the needs of different customers. This is no different than having multiple language audio tracks and allowing the user to switch between tracks. (Joehl, 2011)

This was also raised as an issue by an audience member at the Future of Subtitling Conference referred to earlier, who commented that disabled consumers were still expected to pay full price (Media Access Australia, 2014). Significantly, these online and off-line protesters emphasise their powers as consumers to cease using the service at any time. Indeed when Netflix would not commit to introducing audio description, a new service - Talkingflix - emerged to capitalise on the viewing needs of people with vision impairment through an audio description on demand streaming service to be used in conjunction with broadcast and broadband television and video offerings (Cool Blind Tech, 2014).

When Netflix announced an Australia-New Zealand launch in March 2015 (Novak, 2014), Kingett hypothesised that the move could have an impact on the availability of audio description on Netflix more broadly due to Australia's commitment to both the Web Content Accessibility Guidelines (WCAG) (outlined by other papers in this issue) and the UNCRPD. However, he recognised that as a nongovernment site Netflix was a 'gray area', yet continued to hold some hope regarding the history of disability and Web accessibility advocacy in this country (Kingett, 2014b).

The ongoing mediation between Blind Citizens Australia, the $A B C$ and the federal government regarding the lack of audio description on Australian television (see Ellis, 2014) suggested the provision of audio description was unlikely. Nevertheless, Kingett encouraged Australians and members of the ANP to 'voice [their] thoughts or concerns about accessibility and accessible design, including audio description' (Kingett, 2014b). Subsequently, Netflix and the ABC iView launched their audio description services in the same week.

\section{Content and interface personalisation}

Increasingly, television is being targeted towards specific users' preferences and interests, for example, the content personalisation and recommendation systems characteristic of Netflix. However, people with disability could potentially be left behind again as designers cater for able bodied users. 'Video in the Web', a W3C initiative, seeks to 'make video a first class citizen of the Web'. They argue that the explosive growth in online video and associated audio has created problems related to 'content discovery, searching, indexing and accessibility'.

Television accessibility issues related to both television equipment and programme content arise for people with disability (see O'Connell, 2014). Dual screen interfaces such as television with a tablet or mobile phone are emerging to address these issues. For example, Supple, a project predominately concerned with ubiquitous computing, has the added benefit of allowing users with vision impairment to personalise layout and font size. The project's broader aim is to create an interface which reflects 'the needs and usage pattern of individual users' (Gajos and Weld, 2004). Avanti, another assistive interface, 'dynamically tailor[s] itself to the abilities, skills, requirements and preferences of the users, to the different contexts of use, as well as to the changing characteristics of users, as they interact with 
the system' (Stephanidis, et al., 1998). Finally, the European project 'Gentle user interfaces for elderly people' (GUIDE) is a component which adapts TV based applications to specific users' preferences. GUIDE offers several output modalities in order to compensate for the effects of various impairments. These new developments in dual screen technologies and multimodal interaction illustrate our argument in Disability and new media that digital information should be presented to users in whichever format is most suitable to their specific needs.

\section{Conclusion}

Strictly speaking, digital television does not utilize the Internet and is beyond the scope of this special issue topic, although the problems with bandwidth on the broadcast channel related to providing accessible content, and sign language avatars in particular, has a certain resonance with all digital communications methods. However increasingly it is impossible to separate these two media. Twitter and other social media increasingly play an important role as a backchannel to television viewing. More directly related to accessibility is the ability for hybrid broadcast/broadband delivery systems provide the extra bandwidth to channels to provide additional accessibility options through the Internet. As well as being integrated into the television these accessibility options can also be offered through a second screen such as a tablet computer in conjunction with a traditional television service. With the increasing growth of streaming on demand service, either affiliated with a television station such as the ABC's iView or dedicated services such as Netflix, television is migrating away from its terrestrial broadcast origin to being fully online. As the recent Netflix legal appeal in the United States shows, this transition is causing difficulties as regulatory regimes try to catch up with this form of radical evolution of television from a local to a global audience. This has significant implications for the regulation of accessibility standards, although ironically in many cases these local standards are an attempt to comply with the globally focused UNCRPD enacted by the United Nations.

This paper approached the significance of recent changes to television in the context of increasing the social inclusion of people with disabilities and the recognition of this group as important audiences, publics and users. While a number of theorists have pointed to the stereotypical and discriminatory representation of disability on television (Barnes, 1992; Cumberbatch and Negrine, 1992; Harnett, 2000; Longmore, 1987; Quackenbush, 2011), the inaccessibility of television itself has gone largely unexplored within critical disability studies.

In 2011 Ellis and Kent observed that while disability studies, Internet studies, and media studies share many qualities and approaches - particularly an interdisciplinary perspective and an interest in social justice - there was only limited dialogue and overlap between these fields. The rapid evolution of online television on demand illustrates the already significant overlap and connection between media studies and Internet studies where any distinction between the two is increasingly meaningless. However there is still only limited dialogue between disability studies and these other two fields. As noted above both these areas have much to offer each other. The issues discussed in this paper highlight the importance of this dialogue in a changing media landscape where changing technology has the potential to overlook the participation of people with disabilities.

This inaccessibility of the changing television landscape has not gone unnoticed by people with disabilities, particularly as television makes a further transition to the Internet through streaming services such as Netflix (Haller, 2009; Joehl, 2011; Kingett, 2014a; Mullin, 2012). The digitisation of television has resulted in greater opportunity for access, participation and critique, and significant advancements surrounding legislation for Web accessibility in general. Although an environment focused on digital accessibility, niche audiences and consumer choice should offer great potential for people with disability, as we have discussed in this paper, this is far from automatic.

Although disability and new media theorists such Goggin and Newell (2003), Ellis and Kent (2011), and Jaeger (2012) all highlight the significance of accessible online environments to the social inclusion of people with disability, the importance of accessible television is under-theorised. As discussed throughout this paper, people with disabilities use television as a vital site of information, communication and entertainment. Their right to television accessibility in further mandated by the UNCRPD.

Television accessibility is determined by a number of aspects of the television viewing experience such as selecting and viewing TV content as well as discussing it online (Looms, 2014). Significantly, people with disabilities are also communicating online to advocate for more accessible television, particularly as it transitions to the Internet. As a result of the recent ADA ruling against Netflix, legal commentators are predicting far-reaching impacts on Web accessibility in general, and recommending businesses comply with accessibility guidelines as a matter of course (Goren, 2012).

As Netflix launches in Australia, a country with a rich history of disability advocacy for accessible Web sites, discussions of disability and the media (particularly television) will be forced to move beyond questions of representation to consider the importance of media accessibility.

Accessible broadcast and broadband television represent a significant new frontier in disability media studies. As we consider where to move next in this special issue, the interventions of industry innovation, government legislation and the activism of people with disability are equally important in shaping an accessible new media environment. $\mathbf{F M}$ 


\section{About the authors}

Dr. Katie Ellis is Senior Research Fellow in the Internet Studies Department at Curtin University. She commenced a prestigious Australian Research Council Discovery Early Career Researcher Award studying disability and digital televisions in 2013. She identifies as a person with disability and has previously worked with people with disabilities in the community, government, and in academia. Katie has published widely in the area of disability, television, and digital and networked media, extending across both issues of representation and active possibilities for social inclusion. She has published five books on the topic and is series editor of Routledge Research in Disability and Media Studies. Her current projects include co-editing the Routledge companion to disability and media with Gerard Goggin and Beth Haller, and Disability and social media: Global perspectives (Ashgate) with Mike Kent. E-mail: Katie [dot] ellis [at] curtin [dot] edu [dot] au

Dr. Mike Kent is a Senior Lecturer in Internet Studies at Curtin University. His current research is focused on disability and the Internet as well as higher education and particularly online education. His articles have appeared in Disability and Society, Disability Studies Quarterly, Digital Culture and Education, Journal of Online Learning and Teaching and M/C Journal (Media Culture). He co-authored, with Dr. Katie Ellis, the monograph Disability and new media, and An education in Facebook: Higher education and the world's largest social network, with Dr. Tama Leaver. Mike is @cultware on Twitter and can be found on the Web at www.cultware.com.

E-mail: $m$ [dot] kent [at] curtin [dot] edu [dot] au

\section{Acknowledgements}

The authors would like to thank Melissa Merchant, and Ceri Clocherty for their research assistance. Katie Ellis gratefully acknowledges funding from the Australian Research Council for her Discovery Early Career Researcher Award Project on Disability and digital television (DE130101012), which supported her research for this paper.

\section{Notes}

1. Goggin and Newell, 2003, p. 90.

2. Jaeger, 2012, p. 153.

3. Ibid.

4. Jaeger, 2012, p. 139.

5. Jaeger, 2012, p. 154.

6. Weber and Evans, 2002, p. 437.

7. Springett, et al., 2011, p. 1.

8. Mikul, 2010, p. 5.

9. Mikul, 2010, p. 6.

10. Authority for Television on Demand (ATVOD), 2014, p. 2.

11. Authority for Television on Demand (ATVOD), 2013, p. 10

12. Authority for Television on Demand (ATVOD), 2013, pp. 10-11.

13. Authority for Television on Demand (ATVOD), 2013, p. 11.

\section{References}

G. Annable, G. Goggin and D. Stienstra. 2007. "Accessibility, disability, and inclusion in information technologies: Introduction," Information Society, volume 23, number 3, pp. 145-147. doi: http://dx.doi.org/10.1080/01972240701323523, accessed 23 August 2015.

Australia. Department of Broadband, Communications and the Digital Economy, 2010. "Investigation into access to electronic media for the hearing and vision-impaired: Media access review final report," at http://www.abc.net.au/mediawatch/transcripts/1105 bcd.pdf, accessed 7 January 2014.

Authority for Television on Demand (ATVOD), 2014. "Access services plan 2014-16" (26 February), at http://atvod.co.uk/uploads/files/Access Services Plan 2014-16.pdf, accessed 26 November 2014.

Authority for Television on Demand (ATVOD), 2013. "Provision of video on demand access services 2013 report" (9 December), at

http://atvod.co.uk/uploads/files/Provision of Access Services 2013 Report.pdf, accessed 26

November 2014. 
Blind Citizens Australia, 2013. "Government and ABC fail to deliver on accessible TV for Australia's blind" (11 July), at http://www.vision2020australia.org.au/news/2013-07-11/government-and-abc-failto-deliver-on-accessible-tv-for-australias-blind, accessed 23 August 2015.

C. Barnes, 1992. "Disabling imagery and the media: An exploration of the principles for media representations of disabled people," at http://www.leeds.ac.uk/disabilitystudies/archiveuk/Barnes/disabling\%20imagery.pdf, accessed 23 August 2015.

Cool Blind Tech, 2014. "TalkingFlix, coming soon to speakers near you" (22 April), at http://coolblindtech.com/podcast/talkingflix-4222014, accessed 23 August 2015.

Cornell University Law School, 2010. "47 CFR 79.1 - Closed captioning of video programming," at http://www.law.cornell.edu/cfr/text/47/79.1, accessed 29 January 2014.

B.J. Cronin and S.R. King, 1998. "The development of the descriptive video services," at http://www2.edc.org/NCIP/library/v\&c/Cronin.htm, accessed 8 May 2014.

G. Cumberbatch and R. Negrine, 1992. Images of disability on television. London: Routledge.

E. Ellcessor, 2014. "Hidden from view: Closed captioning, digital labor, and ideologies of ability," paper presented at the 64th annual conference of the International Communications Association (Seattle).

E. Ellcessor, 2012. "Captions on, off on TV, online: Accessibility and search engine optimization in online closed captioning," Television \& New Media, volume 13, number 4, pp. 329-352. doi: http://dx.doi.org/10.1177/1527476411425251, accessed 23 August 2015.

K. Ellis, 2015. "Netflix closed captions offer an accessible model for the streaming video industry, but what about audio description?" Communications, Politics \& Culture, volume 47, number 3, pp. 3-20, and at http://www.rmit.edu.au/media/public-site-media-production/documents/college-of-design-andsocial-context/schools/media-and-communication/cpc-journal/volume-47-issue-3/CPC-vol47-no3-2Ellis.pdf, accessed 23 August 2015.

K. Ellis, 2014. "Digital television flexibility: A survey of Australians with disability," Media International Australia, number 150, pp. 96-105.

K. Ellis, 2012. "It means inclusion: A creative approach to disability and telecommunications policy in Australia," Telecommunications Journal of Australia, volume 62, number 2, pp. 27.1-27.13.

K. Ellis and G. Goggin, 2015. Disability \& the media. New York: Palgrave Macmillan.

K. Ellis and M. Kent, 2011. Disability and new media. New York: Routledge.

K, Gajos and D. Weld, 2004. "SUPPLE: Automatically generating user interfaces," at http://www.eecs.harvard.edu/ kqajos/papers/2004/supple-iui04.pdf, accessed 20 August 2015.

G. Goggin and C. Newell, 2003. Digital disability: The social construction of disability in new media. Lanham, Md.: Rowman \& Littlefield.

W. Goren, 2012. "Must the Internet be accessible to comply with the Americans with Disabilities Act?" (23 June), at http://www.williamgoren.com/blog/tag/21st-century-communication-videoaccessibility-act-of-2010/, accessed 9 May 2014

B. Haller, 2009. "National Association of the Deaf calls out Netflix for lack of captioned 'Wizard Of Oz'," Media dis\&dat (5 October), at http://media-dis-n-dat.blogspot.com/2009/10/national-association-ofdeaf-calls-out.html, accessed 25 June 2010

A. Harnett, 2000. "Escaping the 'Evil Avenger' and the 'Supercrip': Images of disability in popular television," Irish Communications Review, volume 8, pp. 21-29, and at http://arrow.dit.ie/aaschmedart/7/, accessed 20 August 2015.

J. Hattem, 2015. "Court: Netflix doesn't have to comply with disability law" (3 April), at http://thehill.com/policy/technology/237829-court-netflix-doesnt-have-to-comply-with-disability-law, accessed 20 August 2015.

J. Hassell, 2012. "NAD vs Netflix captions lawsuit: Is Lovefilm in the UK even more exposed?" (25 June), at http://www.hassellinclusion.com/2012/06/netflix-caption-lawsuit-uk-implications/, accessed 21 November 2014

P. Jaeger, 2012. Disability and the Internet: Confronting a digital divide. Boulder, Colo.: Lynne Rienner Publishers.

S. Joehl, 2011. "A personal response to Reed Hastings, co-founder \& CEO of Netflix" (22 September), at https://www.ssbbartgroup.com/blog/2011/09/22/a-personal-response-to-reed-hastings-co-founderceo-of-netflix/, acessed 24 September 2014.

J. Kukiewicz, 2013. "We're left out by Lovefilm, say hearing impaired" (10 February), at http://www.choose.net/media/quide/news/left-out-lovefilm-hearing-impaired.html, accessed 21 November 2014

R. Kingett, 2014a. "The accessible Netflix project: Advocates taking steps to ensure Netflix accessibility for everyone," at http://netflixproject.wordpress.com/, accessed 30 January 2014. 
R. Kingett, 2014b. "Will Netflix be inaccessible in Australia and New Zealand?" (19 November), at from http://netflixproject.wordpress.com/2014/11/19/will-netflix-be-inaccessible-in-australia-and-newzeeland/, accessed 19 November 2014.

L. Kubitschke, K. Cullen, C. Dolphi, S. Laurin and A. Cederbom, 2013. "Study on assessing and promoting e-accessibility," European Commission, at http://ec.europa.eu/digitalagenda/en/news/study-assessing-and-promoting-e-accessibility, accessed 3 February 2014 doi: http://dx.doi.org/10.2759/33027, accessed 23 August 2015.

C. Law and G. Vanderheiden, 1998. "EZ access strategies for cross-disability access to kiosks, telephones and VCRS," (16 February) at http://www.dinf.ne.jp/doc/english/Us Eu/conf/csun 98/csun98 074.html, accessed 21 November 2014.

P. Longmore, 1987. "Screening stereotypes: Images of disabled people in television and motion pictures," In: A. Gartner and T. Joe (editors). Images of the disabled, disabling images. New York: Praeger, pp. 65-78.

P. Looms, 2014. "Making TV accessible in the 21st century," In: Y.-I. Liu and R.G. Picard (editors). Policy and marketing strategies for digital media. New York: Routledge, pp. 43-59.

Media Access Australia, 2014. "UK VOD industry has two years to deliver captions or face regulation" (19 November), at http://www.mediaaccess.org.au/latest news/tv-video/uk-vod-industryhas-two-years-to-deliver-captions-or-face-requlation, accessed 21 November 2014.

Media Access Australia, 2012a. "Audio description on TV in the US," at http://www.mediaaccess.org.au/television/audio-description-on-tv/audio-description-on-tv-in-the-us, accessed 12 May 2014

Media Access Australia, 2012b. "Statistics on DVD accessibility in Australia," at http://www. mediaaccess.orq.au/dvds/Statistics\%20on\%20DVD\%20accessibility\%20in\%20Australia, accessed 21 November 2014.

C. Mikul, 2010. "Audio description background paper," Media Access Australia, at https://www.communications.gov.au/sites/g/files/net301/f/Appendix-8-Media-Access-AustraliaBackground-Paper2.doc, accessed 23 August 2015.

J. Mullin, 2012. "Netflix settles with deaf-rights group, agrees to caption all videos by 2014," Ars Technica (10 October), at http://arstechnica.com/tech-policy/2012/10/netflix-settles-with-deaf-rightsgroup-agrees-to-caption-all-videos-by-2014/, accessed 1 January 2014

Netflix, 2015. "Netflix begins audio description for visually impaired" (14 April), at http://blog.netflix.com/2015/04/netflix-begins-audio-description-for.html, accessed 20 July 2015.

M. Novak, 2014. "Netflix is finally coming to Australia and New Zealand in March," Gizmodo (18 November), at http://gizmodo.com/netflix-is-finally-coming-to-australia-and-new-zealand-1660356751, accessed 19 November 2014

T. O'Connell, 2014. "e-Accessibility policy toolkit for people with disabilities," at http://www.e-accessibilitytoolkit.org/toolkit/technology areas/television, accessed 20 August 2015.

OfCom, 2014a. "Review of signing arrangements for relevant TV channels," at http://stakeholders.ofcom.org.uk/binaries/consultations/review-signing-arrangementstv/summary/condoc.pdf, accessed 26 November 2014

OfCom, 2014b. "Subtitling, signing or audio description," at http://consumers.ofcom.org.uk/complain/tv-and-radio-complaints/subtitling-signing-or-audiodescription/, accessed 26 November 2014

OfCom, 2013. "Television access services: Report for the first six months of 2013" (25 September), at http://stakeholders.ofcom.org.uk/market-data-research/market-data/tv-sector-data/tv-accessservices-reports/access-q1q2-13, accessed 26 November 2014

OfCom, 2012. "Ofcom's code on television access services" (18 December), at http://stakeholders.ofcom.org.uk/broadcasting/broadcast-codes/tv-access-services/code-tv-accessservices-2013/, accessed 12 May 2014.

A. Palmer, 2014. "Deaf news: TV comedian targets Lovefilm offices in direct action over subtitles" (13 May), at http://limpingchicken.com/2014/05/13/deaf-news-tv-comedian-targets-lovefilm-offices-indirect-action-over-subtitles/, accessed 21 November 2014

R. Pedlow, 2008. "How will the changeover to digital broadcasting in 2009 influence the accessibility of TV for Americans with disabilities?" Disability Studies Quarterly, volume 28, number 4, at http://dsqsds.org/article/view/130/130, accessed 23 August 2015.

Pesky People, 2012. "Subtitle now! Day of action: 6 June 2012" (5 June), at from http://www.peskypeople.co.uk/2012/06/subtitle-now-day-of-action-6-june-2012/, accessed 21 November 2014 
N. Quackenbush, 2011. "Speaking of - and as - stigma: Performativity and Parkinson's in the rhetoric of Michael J. Fox," Disability Studies Quarterly, volume 31, number 3, at http://dsqsds.org/article/view/1670/1601, accessed 23 August 2015.

J. Robare, 2011. "Television for all: Increasing television accessibility for the visually impaired through the FCC's ability to regulate video description technology," Federal Communications Law Journal, volume 63, number 2, pp. 553-578, and at http://www.repository.law.indiana.edu/fclj/vol63/iss2/10/, accessed 23 August 2015.

S. Sinclair, G. Bramley, L. Dobbie and M. Gillespie, 2007. "Social inclusion and communications: A review of the literature," Ofcom (November), at http://www.communicationsconsumerpanel.org.uk/downloads/Research/LowIncomeConsumers Research/Social\% 20inclusion \%20and\%20communications/Social\%20inclusion\%20and\%20communications.pdf, accesed 24 September 2013.

J. Slater, J-I. Lindström and G. Astbrink, 2010. "Broadband solutions for consumers with disabilities," Australian Communications Consumer Action Network (ACCAN), at https://accan.org.au/files/Reports/Broadband\%20Solutions\%20ED.pdf, accessed 19 November 2014.

M. Springett, M. Rice and R. Griffiths, 2011. "Towards inclusive digital television," Universal Access in the Information Society, volume 12, number 1, pp. 1-3.

doi: http://dx.doi.org/10.1007/s10209-011-0261-9, accessed 23 August 2015.

C. Stephanidis, A. Paramythis, D. Akoumianakis and M. Sfyrakis, 1998. "Self-adapting Web-based systems: Towards universal accessibility," at http://ui4all.ics.forth.gr/UI4ALL-98/stephanidis2.pdf, accessed 20 July 2015.

United Kingdom, 2003. "Communications Act 2003," at http://www.legislation.gov.uk/ukpqa/2003/21/pdfs/ukpga 20030021 en.pdf, accessed 29 January 2013.

United Nations, 2006. "Convention on the Rights of Persons with Disabilities," at http://www.un.org/disabilities/convention/conventionfull.shtml, accessed 4 June 2013.

U.S. Federal Communications Commission (FCC), 2014. "Captioning of Internet video programming," at http://www.fcc.qov/quides/captioning-internet-video-programming, accessed 29 January 2014.

F. Utray, M. de Castro, L. Moreno and B. Ruiz-Mezcua, 2012. "Monitoring accessibility services in digital television," International Journal of Digital Multimedia Broadcasting, volume 2012.

doi: http://dx.doi.org/10.1155/2012/294219, accessed 23 August 2015.

Vision Australia, 2014. "Vision Australia position on audio description on Australia television" (29 September), at http://www.visionaustralia.org/about-us/news-and-media/latestnews/news/2014/09/29/vision-australia-position-on-audio-description-on-australia-television, accessed 21 October 2014.

I. Weber and V. Evans, 2002. "Constructing the meaning of digital television in Britain, the United States and Australia," New Media \& Society, volume 4, number 4, pp. 435-456. doi: http://dx.doi.org/10.1177/146144402321466750, accessed 23 August 2015.

B. Wentz, P. Jaeger and J. Lazar, 2013. "Retrofitting accessibility: The legal inequality of after-the-fact online access for persons with disabilities in the United States," First Monday, volume 16, number 11, http://firstmonday.org/article/view/3666/3077, accessed 23 August 2015.

S. Wildman, 2013. "An open letter to Netflix RE: Subtitles" (13 August) at http://nerdophiles.com/2013/08/13/an-open-letter-to-netflix-re-subtitles/, accessed 28 January 2014.

J. Wolford, 2012. "Netflix will caption all streaming videos by 2014, per settlement" (11 October), at http://www.webpronews.com/, accessed 1 January 2014.

\section{Editorial history}

Received 21 August 2015; accepted 22 August 2015.

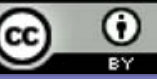

"Accessible television: The new frontier in disability media studies brings together industry innovation, government legislation and online activism" by Katie Ellis and Mike Kent is licensed under a Creative Commons Attribution 4.0 International License.

Accessible television: The new frontier in disability media studies brings together industry innovation, government legislation and online activism

by Katie Ellis and Mike Kent.

First Monday, Volume 20, Number 9 - 7 September 2015

http://journals.uic.edu/ojs/index.php/fm/rt/printerFriendly/6170/4905

doi: http://dx.doi.org/10.5210/fm.v20i9.6170 
